\title{
Göçmen Karşıtlığından İslamofobiye Avrupa Aşırı Sağı
}

Cihan UZUNÇAYIR*

\section{Özet}

Bu makalede son dönemde gittikçe güç kazandığı gözlemlenen Avrupa aşırı sağının göçmen karşıtı politikaları incelemeye alınacaktır. Aşırı sağ kategorisinde değerlendirilen siyasi partilerin çeşitli yerlerde elde ettiği seçim başarıları, faşizmin yeniden Avrupa siyasetine hakim olacağı kuşkularını gündeme getirmiştir. Bu partilerin en ayırt edici vasıflarından birisi siyasal söylemlerini büyük oranda göçmen karşıtlığı üzerine inşa etmiş olmalarıdır. Özellikle 11 Eylül olayları, göçmen karşıtı söylemin yükselişinde önemli bir tarihsel an olmuştur. Bu olaylardan sonra göçmen karşıtlı̆̆ı, İslam karşıtı bir dil üzerinden ifade imkanı bulabilmiştir.

Anahtar Kelimeler: Aşırı Sağ, Göçmen Karşıtlı̆̆ı, Zenofobi, İslamofobi

\section{European Extreme Right: From Anti-Immigration Policies to the Islamophobia}

\begin{abstract}
This article will examine the anti-immigrant policies of the extreme right parties in Europe which has gained strength in last few years. Electoral success of the parties that are considered as extreme right-wing parties has also increased the doubt of a possible dominance of fascism in the European politics once more. One of the most distinguishing characteristics of these parties is their common political discourse that is built upon the anti-immigrant rhetoric. Particularly, the September 11 event has been an historical moment in the rise of anti-immigrant opposition. After this event the opposition has found the possibility of expression through anti-Islamic language
\end{abstract}

Keywords: Extreme Right, Anti-Immigrant Policies, Xenophobia, Islamophobia.

\footnotetext{
* Araştırma Görevlisi, Muğla Sıtkı Koçman Üniversitesi İktisadi ve İdari Bilimler Fakültesi Kamu Yönetimi Bölümü, E-posta: cihanuzuncayir@gmail.com
} 


\section{Giriş}

Geçtiğimiz son yirmi yıl, Batı Avrupa'nın istikrarlı demokrasilerinde aşırı sağ oluşumların ciddi bir güç kazandığı döneme tekabül eder. Sadece Batı Avrupa ülkeleri değil, Avusturya, Kanada ve Yeni Zelanda gibi köklü demokrasi geleneğine sahip ülkelerde de aşırı sağın yükselişine şahitlik edilmiştir. Avrupa'nın neredeyse tüm ülkelerinde bu aşırı sağ partilere rastlamak mümkündür. Fransa'da Front National (FN), Belçika'da Vlaams Blok, Avusturya'da Freiheitliche Partei Österreichs (FPÖ), Danimarka'da Dansk Folkeparti (DF), İtalya' da Lega Nord (LN), Hollanda'da Lijst Pim Fortuyn (LFP), Almanya'da Republikaner Partei (RP), Norveç'te Framstegpartiet (FrP) bunlardan bazılarıdır.

Söz konusu aşırı sağ partilerin gittikçe güç ve destek kazanıyor oluşu, Avrupa semalarında yeniden faşizm hayaletinin dolaşmaya başladığı yorumlarını beraberinde getirmiştir. Ülkeden ülkeye değişen gündemlere sahip olan bu partiler, özellikle göçmen karşıtlı̆̆ı ve yabancı düşmanlığı konusunda benzer argümanların savunuculuğunu yapmaktadırlar. Bu çalışmanın esas amacı da Avrupa'daki aşırı sağ partilerin göçmen karşıtı söylem ve politikalarına odaklanmak olacaktır. Bunun için ilk olarak Avrupa'da aşırı sağın neden yükselişe geçtiği tartışılacaktır. Daha sonra aşırı sağ partilerin özellikleri belirtilerek, bunların klasik faşist partilerden hangi noktalarda ayrıldıkları ortaya koyulacaktır. Devam eden bölümde ise aşırı sağın göçmen karşıtı siyasal gündeminin hangi temel tezler etrafinda oluşturulduğu incelenecek ve 11 Eylül sonrasında bu göçmen karşıtı siyasal söylemin İslam karşıtlığını da içine alarak güç kazanışının kısa bir analizi yapilacaktır.

\section{Aşırı Sağın Yükselişinin Sebepleri}

Aşırı sağ partilerin ortaya çıkışı ve yükselişinin sebepleri üzerine farklı görüşler mevcuttur. Akademideki ve medyadaki en popüler argüman "modernleşmenin kaybedenleri" tezidir. $\mathrm{Bu}$ teze göre aşırı sağ, modernleşmenin sonuçlarından zarar gördüğünü düşünen kitlelerin oylarıyla yükselmektedir. Küreselleşmenin yarattığı kültürel (göçmen), ekonomik (işsizlik) ve politik (Avrupa entegrasyonu) güvensizlik, aşırı sağın oylarının artmasına neden olmaktadır. (Mudde, 2011:9) Bireysel özerkliğin artması ve toplumda fonksiyonel farklılaşma üzerinden anlaşılabilecek modernleşmeye karşı sağ-kanat radikalizm, bu sosyal değişimi geri döndürmenin radikal bir çabası olarak yorumlanabilir. Sosyal farklılaşmanın karşısına ulusal olarak tanımlanan bir topluluk fikrini koyan aşırı sağ; bireyselleşmeye karşı da topluluk içinde bireyin geleneksel statülerinin ve rollerinin söz konusu olduğu ex-ante duruma geri dönüşü savunur (Minkenberg, 2011: 12).

"Modernleşmenin kaybedenleri tezi” her ne kadar aşırı-sağın neden güçlendiği hususunda açıklayıcı bir yaklaşım olsa da, hem çok geniş hem de çok sınırlı olmakla maluldür. Küreselleşme kabaca tüm Avrupa ülkelerini benzer biçimde etkilemesine karşın, popülist radikal sağ partilerin kaderi ülkeden ülkeye değişmektedir. Modernleşme teorisi insanların neden bir siyasi partiye oy verdiğini açıllarken siyasetin sadece talep yönüne dikkati çeker. Fakat siyasetin arz yönü de en 
Tablo-1: 1980'den 2012'ye Batı Avrupa'daki Aşırı Sağ Partilerin Ulusal Parlamento Seçimlerinde Aldıkları Oy Oranlarının Yüzdesi

\begin{tabular}{|l|c|c|c|c|c|c|c|}
\hline & $\mathbf{1 9 8 0 - 1 9 8 4}$ & $\mathbf{1 9 8 5 - 1 9 8 9}$ & $\mathbf{1 9 9 0 - 1 9 9 4}$ & $\mathbf{1 9 9 5 - 1 9 9 9}$ & $\mathbf{2 0 0 0 - 2 0 0 4}$ & $\mathbf{2 0 0 5 - 2 0 0 9}$ & $\mathbf{2 0 1 0 - 2 0 1 2}$ \\
\hline Avusturya & 5.0 & 9.7 & 19.6 & 24.4 & 10.0 & 28.3 & $\mathrm{X}$ \\
\hline Belçika & 1.1 & 1.7 & 6.6 & 10.9 & 13.8 & 14.0 & 7.8 \\
\hline Danimarka & 6.4 & 6.9 & 6.4 & 9.8 & 12.6 & 13.9 & 12.3 \\
\hline Fransa & 0.4 & 9.9 & 12.7 & 14.9 & 12.4 & 4.7 & 13.6 \\
\hline $\begin{array}{l}\text { Almanya } \\
\text { (Fed. Al.) }\end{array}$ & 0.2 & 0.6 & 2.3 & 3.3 & 1.0 & 2.1 & $\mathrm{X}$ \\
\hline $\begin{array}{l}\text { Büyüik } \\
\text { Britanya }\end{array}$ &.-- & 0.6 & 0.9 &.-- & 0.2 & 0.7 & 1.8 \\
\hline İtalya & 6.8 & 5.9 & 18.0 & 25.8 & $4.3^{*}$ & $8.3^{*}$ & $\mathrm{X}$ \\
\hline Hollanda & 0.8 & 0.7 & 2.9 & 0.6 & 11.4 & 5.9 & 12.7 \\
\hline Norveç & 4.5 & 8.4 & 6.0 & 15.3 & 14.7 & 22.5 & $\mathrm{X}$ \\
\hline İsveç &.-- &.-- & 4.0 &.-- & 1.5 & 3.0 & 5.7 \\
\hline İsviçre & 3.8 & 6.3 & 11.9 & 18.7 & 26.6 & 30.0 & 26.6 \\
\hline
\end{tabular}

Kaynak: (Minkenberg, 2013; 20) X= O dönemde gerçekleştirilen seçime katılmamış

*: Alleanze Nazionale hariç, Movimento Sociale-Fiamma Tricolore, Lega Nord, Mussolini, Rauti dahil.

Ülkelerdeki partiler: Avusturya: FPÖ; Belçika: Vlaams Blok, Front National; Danimarka: Fremskridsparti, Dansk Folkeparti; Almanya: Republikaner, DVU, NPD; Büyük Britanya: British National Party, National Front, Democratic Unionist Party; İtalya: Sociale İtaliano, Alleanze Nazionale, Movimento Sociale-Fiamma Tricolore, Lega Nord; Hollanda: Center Party, Centrum Democrats, List Pim Fortuyn, Party of Freedom; Norveç: Fremskrittsparti; İsveç: Ny Demokrati, Severigedemokraterna, Nationaledemokraterna; İsviçre: Schweizer Volkspartei-Union Démocratique du Centre; Autopartei, Schweizer Demokraten, Lega dei Ticinesi

az onun kadar önemlidir. Konunun arz yönüyse aşırı-sağ siyasi partilerin seçmenlerin hoşuna gidecek siyasi çözümler önermesidir. Bu partiler ana-akım partilerin görmezden geldiği ama nüfusun büyük bir kısmını derinden endişelendiren suç, yolsuzluk, Avrupa entegrasyonu ve göç gibi meseleler üzerinden güç sağlayabilmektedir (Mudde, 2011:9).

Avrupa'da aşırı sağ hareketlerin yükselişi, giderek artan siyasal hoşnutsuzluk ve yabancılaşmaya da bağlanabilmektedir. Siyasi kurumların ve politikacıların seçmen nezdinde itibar kaybı yaşıyor olmaları, aşırı sağ partilerin oy oranlarını yükseltebilmesi için bir fırsat alanı yaratmaktadır. Sisteme yabancılaşan ve düzeni protesto etmek isteyen seçmenler, aşırı sağ partilere oy vererek ve/veya bu partileri destekleyerek tepkilerini ifade edebilmektedir (Rydgren, 2007: 251). Birçok seçmenin, köklü partilerin büyüme, işsizlik, yolsuzluk, suç, uyuşturucu ve göç gibi önemli konulardaki politik tutumlarına karşı duyduğu memnuniyetsizlik ve güvensizlik, aşırı sağ partilerinin önünün açılmasına imkân sağlamıştır (Karapin, 1998:214). 
Aşırı sağın yükselişini açıklamaya çalışanların üzerinde durdukları bir başka husus da göçmenler sorunudur. 1980'lerin sonu ve 90'ların başından itibaren Batı Avrupa'daki göçmen nüfusu, Eski Yugoslavya, Sovyetler Birliği ve Doğu Avrupa'dan gelen göçlerle birlikte artış göstermiştir. Aşırı sağ partiler, bu göçlerin ortaya çıkardığı sosyal etkilerden yararlanmaya çalışıı̧lardır. Göçmen-karşıtı aşırı sağ partiler, göçmenlerin işsizliği ve suç oranlarını artırdığı tezini işleyerek, bu sorunlardan şikâyetçi olan kitleleri kendi saflarına katmayı başarmışlardır (Karapin, 1998:214). Çalışmanın esas konusu olan bu husus ileride daha geniş biçimde açımlanmaya çalışılacaktır.

1980'den bu yana etkisi ve yaygınlık alanı genişleyen medya ağını kullanma konusundaki becerileri de, aşırı sağ partileri diğerleri önünde daha avantajlı bir konuma getirmiştir. Parti bağllığının azaldığı ve oy bloklarının çözüldüğü yeni dönemde, yurttaşlar siyasi gelişmeleri çoğunlukla medyadan takip etmeye başlamışlardır. Aşırı sağ partilerin liderleri de çoğu zaman medyatik yüzleriyle popüler figürler haline gelmişlerdir. Bu liderler medya ağını kullanarak siyasi söylemlerini daha geniş kitlelere ulaştırabilmenin peşinde koşarken; medya da, haber ve eğlence değeri yüksek bu figürleri ön plana çıkararak daha fazla kitle tarafından izlenebilir hale gelmeyi hedeflemiştir. Böylelikle iki tarafın da birbirinden faydalandığı simbiyotik bir ilişki düzeni kurulmuştur (Vural, 2005: 216-17). Bunun yanı sıra son dönemde oldukça yaygınlaşan sosyal medya kullanımının da aşırı sağın yükselişindeki etkisine değinmek gerekir. Daha çok gençler arasında kullanımının yaygın olduğunu söyleyebileceğimiz sosyal medya kanalları, aşırı sağ fikirlerin rahatça dolaşıma sokulabildiği, kendisi gibi düşünenlerin sosyal ağlar vasıtasıyla birbirini kolaylıkla bulabildiği bir iletişim ortamının inşa edilebilmesine imkân sağlamaktadır. $\mathrm{Bu}$ durumun, gençlerin diğer yaş gruplarına oranla daha fazla aşırı sağ siyasi fikirlere yatkın olmasıyla alakalı olduğunu da belirtmeliyiz. İngiltere'deki bir think-tank kuruluşunun Avrupa'daki aşırı sağ siyasi partilerle ilgili yaptı̆̆ı bir araştırma, bu partilere üye olanların üçte ikisinin otuz yaşından daha genç bireylerden oluştuğunu bulgulamıştır. Aynı zamanda bu araştırma, gençlerin aşırı sağ partilere üyeliğinin diğer partilere oranla daha fazla olduğu bulgusunu da ortaya koymaktadır (Lifland, 2013:10).

Bütün bu sebeplerin Batı Avrupa'da aşırı sağ hareketlerin yükselişinde birer pay sahibi olduğunu söyleyebiliriz. Fakat bu nedenlerin hiçbirisi durumu tek başına açıklayabilme gücüne sahip değildir. Kapsayıcı bir açıklama çerçevesinin, bu sebeplerin tümünü içine alan bir yaklaşıma ihtiyaç duyduğunu belirtmek gerekir. Böyle bir açılama çerçevesi Piero Ignazi tarafından geliştirilmiştir. Ignazi, 1980'den sonra aşırı sağ sahnenin “yeni” ve "eski” tipte partiler tarafından paylaşıldığını savunur. "Eski” tip partiler gitgide siyasi arenayı terk ederlerken, "yeni" tip partiler, siyasi ve kültürel düzeydeki firsat alanlarından faydalanan becerikli siyasi girişimciler eliyle, siyasete ve sisteme güvenini yitirmiş seçmen kitlesini yeni meseleler üzerinden mobilize edebilme gücüne sahip olmuşlardır. Sosyo-ekonomik (post-endüstriyelleşme) ve sosyo-kültürel (post-materyalizm) değişim süreçleriyle birlikte ortaya çıkan yeni mağdurların ve yeni maddi ve gayri-maddi kaygıların sözcülüğünü üstlenen bu liderler önemli bir güç elde etmişlerdir. Başarısızlık ve yolsuzluk örnekleriyle itibar kaybeden yerleşik siyaset üzerinden, parlamenter demokrasiye eleştiriler yöneltmişlerdir. Bu kurumların karşısına halk iradesini koyarak, 
herkesten daha demokrat oldukları iddiasını öne sürmüşlerdir. Bu şekilde kendi seçmenleri nezdinde bir meşruiyet elde etmeyi başarabilmişlerdir (Vural, 2005: 225-26).

\section{Aşırı Sağ Partilerin Özellikleri}

İlk olarak incelemeye konu edilen parti ailesinin literatürde farklı isimlendirilmelerle anılabildiklerini belirtmek gerekir. Bu partiler farklı yazarlar tarafından faşist, neo-faşist, neopopülist, yeni-popülist, radikal-sağ, radikal-sağ popülist, popülist, sağ-kanat popülist, göçmenkarşııtı ve yeni-sağ olarak adlandırılmışlardır. (Hainsworth, 2008: 9) Mevcut kavram enflasyonunu gözönüne alarak söz edeceğimiz partileri aşırı sağ partiler olarak ifade etmeyi uygun bulduk. Avrupa ülkelerindeki aşırı sağ partilerin tek tek incelenmesi, bunlardan bazılarını popülizmle ve/veya radikallikle ilişkilendirmenin daha uygun olacağı bir durumla karşılaşılmasını beraberinde getirebilir. Ancak burada, bütün bu organizasyonları kapsayan bir çatı ifade olarak kullanılabileceğini düşünerek aşırı sağ terimini tercih ettik.

Her ülkenin kendi özgül şartları içerisinde ortaya çıkan çağdaş aşırı sağ partilerin, "ideoloji” bakımından heterojen ve örgütlenme bakımından karmaşı olmaları, birçok yazarı bu partileri daha iyi anlayabilmek, onların merkez sağdan ve "politik aşırılığın" diğer biçimlerinden hangi yönlerde ayrıldıklarını anlayabilmek için ideal tipler ve kategoriler geliştirmeye sevk etmiştir. $\mathrm{Bu}$ ayırıcı özelliklerin neler olduğuna dönük de farklı görüşler mevcuttur. Terminolojik dağınıklığın etkisi burada da kendisini göstermektedir. Nitekim Mudde, literatürde aşırı sağın 26 değişik tanımının varolduğunu ve bu tanımlamalarda aşırı sağın 58 farklı ayırıcı özelliğinin bulunduğuna dikkati çekmektedir. Bu özelliklerden beş tanesi tüm tanımlamaların en az yarısında ortak kullanılmaktadır: Milliyetçilik, rrkçılık, zenofobi, anti-demokrasi ve güçlü devlet vurgusu. Bir hareketi aşırı sağ kategorisine dahil etmek için kimi yazarlar listelerindeki bütün özelliklerin mevcut olduğu durumları ararken; kimileri bu kriterlerden bazılarının varlığını yeterli görmektedir. Karma yaklaşımı benimseyen üçüncü bir anlayış ise dışlayıcı özelliklerden en az birini (milliyetçilik, rrkçlık veya zenofobi) ve güçlü devlet vurgusunun mevcudiyetini yeter koşul kabul etmektedir (Mudde, 1996: 229).

Aşırı sağ partilerin faşizmle olan ilişkisi bu partilerle ilgili gündemi en çok meşgul eden konulardan bir tanesi olmuştur. Hiç kuşku yok ki Avrupa'daki partilerin, hareketlerin, siyasi kültürlerin ve ülkelerin çeşitliliği doğrultusunda bazı partilerin faşizmle ve onun temel referans noktalarıla ilişkisi daha belirgin olmaktadır (Hainsworth, 2008: 16). Bu nedenle savaş sonrası Avrupa'da, özellikle faşizm geçmişi olan ülkelerdeki aşırı sağın ideolojik gövdesi tarihsel (iki savaş arası) faşizmin yeniden yorumlanmasıyla desteklenmiştir (Ignazi, 2003: 21). Böylelikle 1980'lere giden süreç neo (yeni) sıfatını sadece yeni kuşak partiler olmalarıly değil, gerçek manada faşizmi yenilemeleriyle/modernleştirmeleriyle de hakeden yeni-neofaşist partilerin yükselişe geçtiği dönem olmuştur (Bora, 2006: 149). Griffin, iki savaş arası döneme özgü olarak ifade ettiği faşizm ve Nazizm deneyimlerinin tekrar edilemezliğini vurgularken, yine de faşizmin demokratik ya da demokratikleşme yolundaki ülkelerin aşırı sağ hareketleri için kalıcı bir unsur olmaya devam edeceğini ve örgütlü yabancı düşmanlığı ile ultra-milliyetçiliğe kaynak sağlamayı 
sürdüreceğini savunur. Ona göre Avrupa'daki faşist alt kültürün salimen varlı̆̆ını koruması ve mevcut aşırı sağ partilerin iki savaş arası faşizmle yapısal akrabalığı faşizmle ilişkinin güncelliğini koruyacağının açık delilleridir (Griffin, 2014:267-288).

Kimi (neo) Marksist ve Griffin gibi birkaç Marksist olmayan yazar faşizm ifadesini -neo önekini kullanarak ya da kullanmayarak- Avrupa aşırı sağındaki partiler için kullanmayı sürdürmektedirler. Onlara göre bu partiler 1930'lardaki fenomenin son örnekleri olmaktan daha fazla bir anlam taşımamaktadır (Mudde, 1996: 230). Avrupa aşırı sağı içerisinde kategorize edilebilecek bu partiler, gerçekten de iki savaş arası dönem faşizm örnekleriyle doğrudan bir benzerlik ve tarihsel devamlılı̆̆a sahip midir? Bu noktada incelemeye konu ettiğimiz aşırı sağ partilerle klasik faşist ${ }^{1}$ partilerin karşılaştırılması, hem sınıflandırmanın netleştirilmesi hem de söz konusu partilerin özelliklerinin daha iyi anlaşılması açısından faydalı bir girişim olacaktır.

Faşizmin tanımına ilişkin yine geniş bir literatürün varlığından söz edebiliriz. İkinci Dünya Savaşı’nın "faşists" ve "anti-faşist" güçler arasında bir çatışma olduğu düşüncesine kolaylıkla varıldığı için kavram, baskıcı olarak görülen, otoriter ya da seçkinci herhangi bir siyasal rejimi veya eylemi itham etmek üzere duygu yüklü bir kelime olarak savaş sonrası nesillere aktarılmıştır. Özellikle sol akademik dilde bunun yerleşik bir alışkanlık olduğunu söylemek yanlış olmaz. Esasen bu çevrede faşizm kavramının hem türdeş hem de abartılı (enflasyonist) kullanımı, İkinci Dünya Savaşı'nın çok öncesinde başlamıştır (Griffin, 2014:22-24). Haliyle bu durum faşizm kavramının zihinlerde bulanık bir biçimde yer etmesine sebep olmuştur. Terminolojiye ilişkin böyle bir sıkıntının varlığını belirttikten sonra klasik faşizmin ne olduğunu incelemeye geçebiliriz. Bu noktada derinlemesine bir faşizm analizi yapmak bu makalenin gayesi değildir. $\mathrm{Bu}$ nedenle faşizmin genel kabul gören bazı tanımlarına ve özelliklerine değinerek bunların bugünkü aşırı sağ siyasi hareketle ilişkisini incelemeye geçeceğiz.

Faşizmin 1919 ile 1945 yılları arasında Mussolini önderliğindeki siyasal güce verilen isim olduğu ve 1925-1943 arasında İtalya'da kurulan diktatörlük rejiminin resmi ideolojik temelini oluşturduğu konusunda bir mutabakattan sözedebiliriz. İtalyanca fascismo kavramının İngilizceleştirilerek faşizm halini almasıyla kavram, İtalya dışındaki olgular için de kullanılmaya başlanmıştır (Griffin, 2014, 21). Peki faşizm nedir? Hangi özellikler bir hareketi faşist yapar? Michael Mann’e göre "faşizm en özlü ifadesiyle, "paramilitarizm aracilığıyla aşkın ve arınmış (cleansing) bir ulus-devlet peşinde olma halidir." Mann'in faşizm analizinde temel ayırıcı unsurlar olarak milliyetçilik, devletçilik, aşkınlık, arınma ve paramilitarizm ön plana çıkar (Mann, 2004: 13-17). Passmore ise faşizmi "dışlayıcı biyolojik, kültürel ve/veya tarihsel terimlerle tanımlanan ulusu öteki tüm sadakat kaynaklarının üzerinde tutma ve mobilize bir ulusal topluluk yaratma peşinde koşan ideolojiler ve uygulamalar kümesi” olarak tanımlar. Faşizm, sosyalizmle feminizmin yenilgiye uğratılmasını ve mobilize bir ulus yaratılmasını, halk adına hareket eden, karizmatik bir lideri bulunan ve kitlesel, militarize bir partide temsil bulmuş yeni bir seçkin grubunun iktidara gelmesine bağlı sayar. Faşistler, sosyalizm

1 Yazının bundan sonraki kısmında iki savaş arası dönem (1919-1945) faşizmlerine karşılık olarak klasik faşizm ifadesi kullanılacaktır. 
ve feminizme karşı ortak nefretleri nedeniyle muhafazakarlıkla ilişkilendirilir, ancak ulusun çıkarlarının bunu gerektirdiği düşünüldüğünde muhafazakar çıkarlar (aile, mülkiyet, din, üniversiteler, kamu hizmetleri) çiğnemeye hazırdırlar (Passmore, 2014: 47) Robert Paxton’a göre ise faşizm; "halkın çöküşü, aşağılanışı ya da mağduriyetine dair takıntılı bir fikirle ve bunların yerini alacağına inandığı birlik, enerji ve saflık kültleriyle belirlenen bir siyasi davranış biçimi olarak tanımlanabilir. Burada geleneksel seçkinlerle gergin ama verimli bir işbirliği içinde çalışan kendini bu işe adamış milliyetçi militanların kitle temelli partisi, demokratik özgürlükleri terk etmiş, kurtarıcı bir şiddetle ve etik ya da kanuni sınırlamalar olmaksızın içeride temizlik, dışarıda yayılma hedeflerinin peşine düşmüştür (Paxton, 2014: 363).” Tanıl Bora ise alıntıladığımız yazarların belirttiği unsurları da içine alan oldukça geniş bir faşizm tanımı getirir. Buna göre faşist diktatörlük rejimleri, "topyekün toplumsal denetimi, bu denetimin vasitası olarak korporatif temelde sıkı bir "örgütlü toplumu”, dinsel mahiyette bir devlet kültünü, yoğun bir ırkçı-milliyetçi ritüel ekonomisini, bu tapınma etrafında hep yeni vesilelerle tavda tutulan bir toplumsal seferberliği, komünizmin insani-ahlaki problemlere dek tüm sorunların kaynağı bir salgın hastalık olarak şeytanlaştırılmasını, milli düşman ya da "zararlı" veya "aşağı" addedilen insanların/toplulukların tenkilini, arzulanan her hedefe muktedir olunabileceği cinneti içinde hudutsuzlaşmış bir araçsal rasyonaliteyi, milli hedeflerle bu araçsal rasyonaliteyi bağdaştıran asketik bir çalışma ve üretim etiğini, askerileştirme ve sembolik ve fiili savaş hazırlığını, olağanüstü semiren ve başına buyruklaşan baskı aygıtının teknisyence zulmünü tesis etmişlerdir (Bora, 2006: 138)." Klasik faşizmle ilgili bunlardan başka çeşitli tanımlara yer vermek mümkündür. Ancak faşizmle aşırı sağın ne ölçülerde benzerlikler taşıdığının ya da hangi noktalarda farklıklara sahip olduğunun izahına geçerken bu bilgilendirmenin yeterli olacağı kanısındayız. Faşizmin ne olduğuna açıklık getirdikten sonra aşırı sağla halihazırdaki ilişkisinin boyutlarını tartı̧̧maya geçebiliriz.

Her şeyden önce demokrasiye yaklaşımları bakımından klasik faşist partiler ile çağdaş aşırı sağ partiler birbirinden ayrılırlar. Klasik faşist partiler parlamenter demokrasiye, liberal demokratik devlete, liberalizm, sosyalizm ve kozmopolitanizm karşıtı bir duruşa sahiptirler. Buna karşın yeni-aşırı sağ partiler ideolojik olarak demokrasiye muhalif değildirler. Demokrasiyi elitlerden ve yozlaşmış siyasetçilerden kurtarmak istediklerini iddia ederler. Seçmenleri bürokratik devletin, refah devletinin, parlamenter demokrasinin ve catch all partilerin etkisinden azade kllarak, demokrasiyi kurtarma çabasında olduklarını savunurlar. Demokrasiyi yıkma gibi bir amaçları olmamasına karşın, onun liberal ilkelerle donatılmış olmasını da istemezler. Savundukları daha ziyade anti-liberal bir demokrasi tasavvurudur. Bu sebeple kültürel çoğulculuk ilkesini ve azınlık haklarını reddederler. Halkı homojen bir blok olarak tanımladıkları için, "diğer"lerini bozuk ve tehditkâr olarak görme eğilimindedirler. Saf çoğunlukçu ve liberal kontrolü zayıflatılmış bir demokrasiyi ideal olarak sunarlar (Mudde, 2011:7).

İkinci olarak aşırı sağ partiler, devlet destekli programlar aracıllğıyla ulusal ve yerel kültürü korumayı amaçlayan korporatist bir devlet anlayışını savunmazlar. Bunun yerine mevcut radikal sağ milliyetçilik, çok kültürlü bir toplum inşasından, göçmenlerin işgalinden, Amerikan kültürünün hegemonyasından, bürokratik devletten kendisini özgürleştirmiş "otantik bir sivil 
toplum" fikri üzerine kuruludur. Faşist partilerin korporatist ideolojinin aksine yeni aşırı sağ siyasal partiler serbest piyasa ekonomisini desteklerler (Zaslowe, 2007:64-65).

Yeni aşırı sağ partileri klasik faşist akımdan ayıran bir diğer unsur, rrkçılık anlayışının değişen niteliğidir. Biyolojik üstünlük tezleri üzerine bina edilen bir ırkçllık anlayışın esas rengini verdiği klasik faşist ideolojinin aksine yeni aşırı sağ hareketler, yeni bir ırkçılık tipinin savunuculuğunu yapmaktadırlar. Taguieff in (Taguieff, 2001) "farklılıkçı ırkçlık" olarak tanımladığı bu yeni ırkçlık tipi, ayrımı biyolojik farklılıklar üzerinden değil de, kültürel farklılıklar üzerinden kurma eğilimindedir. Bu rrkçılık, biyolojik üstünlük ya da aşağllık gibi iddialar üzerinden kendisini ifade etmez. Daha ziyade, bunları belirleyenin kültürel karakterler olduğu üzerinde durur. $\mathrm{Bu}$ tip ırkçılık anlayışında biyolojik üstünlük fikri yerini farklılık, gelenek ve yaşam biçimlerinin uyuşmazlı̆̆ına bırakmaktadır (Yumul, 1998:142).

"Farklılıkçı ırkçılık" söyleminin inşasında post-modernizm tartışmalarının fark ve tikellik kavramlarının önemli bir bileşen olarak kullanıldığını belirtmek gerekir. "Evrensellik" ve “(evrensel) insanlık” kategorilerinin sorgulanması, kültürlerin ve etnilerin biricikliğini pekiştirmek için değerlendirilmiştir. Bu biricikliğin bütün kültürleri kendi içinde değerli kıldığ ve bunların aynı ölçütlerle değerlendirilemeyeceği tespiti, yine post-modernizm tartışmalarında ön plana çıkan "farklı olma hakkı" kavramı ve çoğul(cu)luk vurgusuyla desteklenerek; kültürlerin ve etnilerin birbirine karışmaması gerektiğini vazeden, ayrımcı ve dışlayıcı bir kültürel ırkçllı̆̆a dayanak yapılmıştır. Bu durum kültürel ırkçı söyleme yabancı düşmanlığını daha "medeni" ve "demokrat" bir kisve altında yapma imkânı sunmuştur (Bora, 2005:24849). Örneğin Fransa'daki Front National (FN) dünyada farklı ırklar, farklı etnik gruplar, farklı kültürlerin yarattığı çeşitliliği korumanın zorunluluğunu kanıtlamaya çalışır. Bunun için de ayrışmış, organik milletlerden oluşan bir toplumda, azınlıklara dinleri ve etnik kökenlerine bağlı olarak farklı hak ve görevler tanınmasının gerekliliğini savunur (Vardar, 1997:34). İlk bakışta zararsız bir öneri gibi görünen bu tez, esasında çoğulculuğun olumlu çağrışımlarının ardına gizlemiş bir ırkçı anlayışı bünyesinde barındırmaktadır. Bütün ırkların ya da etnik grupların ayrı kompartımanlarda yaşadığı ve bu grupların birbirine karışmasına müsaade edilmeyecek bir düzen tasavvuru zihinlerde mevcuttur.

Yeni aşırı sağ partiler kendileri için uygun görülen bu Nazizm/faşizm benzetmesini tam anlamıyla reddetmezler. Buna karşın Nazizm/faşizm tarihinin değerlendirilmesine seçmeci bir bakış açısıyla yaklaşırlar. Onlar açısından faşizm, içerisinde "olumlu ve olumsuz yönleri" olan "nötr" bir tarihsel malzemedir. Bu yüzden geçmişe normatif değerler üzerinden değil de tarihsel olarak bakılması gerektiğini iddia ederler. Özellikle soykırımla ilgili verilerde kimi yerlerde yanlışlıklar olduğunu öne sürerek, şüpheler ortaya atarak, anti-faşist cephenin gerçekleştirdiği katliam örneklerini öne çıkararak faşizmin suçunu "görelileştirmeye" ve bir nevi geçmişi "aklamaya” çalışırlar (Bora, 2005:242-43). Örneğin Nazizm geçmişine sahip Avusturya'da aşırı sağ partiler, yasal sınırlamaların da etkisiyle Nazi rejimine övünçle sahip çıkma imkanına sahip değillerdir. Bunun yerine yukarıda ifade edildiği gibi Nazilerin işlediği katliamlar hafife alınır, yer yer inkar edilir. Kimi zaman da nasyonal sosyalizmin "olumlu" yanlarına (örneğin otobanların yapılması, istihdam politikası vs.) vurgu yapılır (Boztepe, 1997:96). 
Aşırı sağ partiler mitik bir geçmiş imgesi yaratmak yerine, geleceğe dönük bir imaj ortaya koymaya çalışırlar. Faşist geçmişi normalleştiren ama mitikleştirmeye çalışmayan yaklaşımları da bu yüzü geleceğe dönük parti imajı yaratma çabasının ürünü olarak görülebilir. Bu hareketler, kendilerini sadece kendi geçmişlerinden değil, "yerleşik" partilerden, “düzen partileri”nden tamamen farklı, yepyeni oluşumlar olarak sunarlar. Jorg Haider ve Umberto Bossi'nin dile getirdiği "sağ-sol değil ileri” şiarı, parti sisteminin çözüldüğü bir dönemde, "eski” partilerden bıkmış, yüzer-gezer veya eskiden oy kullanmayan seçmeni aşırı sağ partilere çekmiştir.

Özet olarak diyebiliriz ki aşırı sağ partiler kimi özellikleri itibariyle klasik faşist partileri andırıyor olsalar bile, birçok bakımdan onlardan ayrı, yeni bir parti ailesi olma özelliği gösterirler. Değişen siyasi, ekonomik ve sosyal koşullar doğal olarak klasik faşist ideolojinin ilk çıktığı dönemde olduğu gibi savunulabilmesini imkânsız hale getirmiştir. Buna bir de faşizmin kabarık sabıka dosyasını eklediğimizde bu farklılaşmanın kaçınılmaz olduğu daha net anlaşılır. Zaten seçmenlere, “eski” parti anlayışını değiştireceğini vaat ederek, yeni bir siyaset anlayışı inşa edeceğini söyleyerek oy toplamaya çalışan bu partilerden, uzun zaman önce mahkûm edilmiş bir geçmişi yeniden canlandırarak siyaset sahnesinde yer kapmaya çalışmasını beklemek gerçekçi olmazd. Nitekim bu partiler de beklenildiği gibi zamana ayak uydurarak, yeni dönemin koşullarına adapte edilmiş bir siyaset anlayışı geliştirmeye çalışmışlardır. Bu anlamda Avrupa'daki göçmen olgusu aşırı sağ siyasi partilerin söylem bagajında oldukça önemli bir yere sahip olmuştur. O yüzdendir ki kimi yazarlar bu partileri göçmen karşıtı partiler şeklinde siniflandirmaya tabi tutmaktadırlar (van der Brug vd., 2000)

\section{Aşırı Sağ ve Göçmen Karşıtlığı}

Avrupa'da nüfusun oldukça önemli bir kısmını oluşturan göçmenler, aşırı sağ siyasi partilerin negatif söylemlerinin mağduru konumundadırlar. Neredeyse bütün aşırı-sağ partiler ülkedeki ya da kıtadaki sorunların esas sorumlusu olarak göçmen nüfusu görmekte ve göstermektedirler. Güvenlik anlayışının Soğuk Savaş’ın bitimini takip eden süreçte değişmesiyle birlikte, göç olgusu ve göçmen kitleler birer "güvenlik sorunu” olarak kodlanmışlardır. Göçmenleri, güvenliği zayıflatması muhtemel kritik unsurlar olarak gören bu yeni bakış açısı, aşırı-sağ partiler için istismar konusu olmuştur. Hal böyleyken çıkagelen 11 Eylül olayları ve peşisıra gerçekleşen Madrid, Londra ve Paris saldırıları Avrupa'nın gündemini iyiden iyiye güvenlik merkezli bir noktaya taşımıştır. 11 Eylül olaylarına karışan teröristlerin saldırı için göç yollarını kullanmış olması ve daha sonra Avrupa'da gerçekleşen saldırılarda da yerleşik göçmenlerin payının olduğunun ortaya çıkması, göçmenlerin birer tehdit potansiyeli olarak görülmelerine yol açmıştır (Köşer Akçapar, 2012: 563-67). Aşırı sağ partiler de Avrupa genelinde yaygınlaşan bu göçmen karşıtı histeriyi oya tahvil etmenin uğraşı içerisinde olmuşlardır. Aşırı sağ partiler, göçmenlere ilişkin toplumda varolan olumsuz önyargıların altını çizerek, onların dışlanması gerektiği tezini işlerler. Bu önyargıların yeniden üretimi, aşağı yukarı her ülkede benzer kalıplar üzerinden sürdürülür. Göçmenlerin suç oranını artırdığı, ülkeye hastalık getirdikleri, yerli halkın iş imkanlarını ellerinden aldıkları, ülkede ücretlerin düşmesine sebep oldukları, refah devletini 
suistimal ettikleri, bulundukları ülke kendilerininmiş gibi davrandıkları, paralel toplum inşa ettikleri, okullardaki eğitim standartlarını düşürdükleri, kendi içlerinde kadınları dışladıkları gibi suçlamalar sürekli tekrarlanır (Council of Europe, 2011: 14).

Refah şovenizmi, aşırı sağ partilerin göçmen karşıtı tutumlarının anlaşılmasında önemli bir kavram olarak ön plana çıkar. Refah şovenizmi, daha zengin olan ülkelerin, bu zenginliklerini yabancılarla (göçmenler olarak okunabilir) paylaşmak istememesi olarak tanımlanabilir. $\mathrm{Bu}$ gönülsüzlügün arkasında küreselleşme gibi süreçlerle birlikte durumlarının daha da kötüye gidebileceği korkusunu görebilmek mümkündür. Özellikle refah devleti uygulamalarının yaygın olduğu ülkelerde, göçmenlerin devlet olanaklarından faydalanıyor olması özellikle sorun edilebilmektedir. Göçmenlerin bır kısmının vergi ödememesi ya da diğer sosyal harcamaların finanse edilmesinde herhangi bir katkı vermemesi üzerinden bir tür kızgınlık hissi gelişmektedir (van der Waal vd., 2011). Bunun yanında göçmenlerin iş alanlarında rekabeti artırdığ 1 ve ücretlerin düşmesine neden oldukları iddiasını da refah şovenizmiyle ilintilendirebiliriz. Aşırı sağ partiler ise böyle bir durumda vatandaşlik haklarıyla kaynaklara erişimde "yerli halkın" (autocthons) öncelikli olması gerektiğinin önemine vurgu yapmaktadırlar. Özellikle Norveç, Hollanda gibi Avrupa ülkelerinde bu refaha erişimde yerlilerin önceliği hususunda önemli bir uzlaşmanın varlığı dikkati çekmektedir. Hatta kimi zaman bu aşırı sağ talepler anaakım parti temsilcilerini de etkileyebilmektedir. Nitekim İngiltere'de İşçi Partisi’nden Gordon Brown Maliye Bakanı olduğu günlerde, "Britanya'daki işler, Britanyalı işşilerindir" diyebilmiştir (Wiggen, 2012:593). Hal böyleyken, sadece maddi imkanların bölüşümü sorunu olarak değil de, göçmenlerin tüketim alıskanlıklarının farklılığı itibariyle de refah şovenizminin etkisinden söz edilebilir. Tüketim yeteneğinin hem zevk (taste) hem ekonomik kabiliyet (refah) anlamında siyaseten kimlik kurucu bir şiara dönüştüğü bir ortamda, bu kabiliyete sahip olmayanlara karş1 bir üstünlük ve ayrıcalık talebi ileri sürülebilmektedir (Bora, 2005: 254).

Aşırı sağın ideal "ulusal kimlik" tanımı da onların göçmen karşıtı tututmuyla alakalıdır. Yukarıda aşırı-sağın klasik ırkçlığı terkederek yeni tür bir ırkçı anlayışa geçiş yaptığını belirtmiştik. "Farklılıkçı ırkçlık" olarak ifade edilen bu yeni ırkçı görüşe göre farklı halklar, eşsiz ulusal karakterini korumak için birbirinden ayrı tutulmalıdır. Çünkü farklı etnik kültürlerin karışması bir kültürel yok olmaya neden olabilir. Bu farklı etnisitelere hiyerarşik olarak üstünlük ya da aşağılık payesi verilmez. Bunların yalnızca farklı ve karşılaştırılamaz oldukları öne sürülür (Rydgren, 2008:745). Söz konusu "farklılıkçı rrkçı" yaklaşımın ilk savunucularından birisi Fransa'da Jean Marie Le Pen'in kurduğu ve bugün liderliğini kızı Marine Le Pen'in yaptığı Front National olmuştur. Parti, Fransız milliyetçisi tutumunu diğer halkları küçümseyen bir yaklaşım olmadığını savunurken, esas amaçlarının "Fransız kimliğini ve medeniyetinin temel değerlerini korumak" olduğu hususunda ısrar etmiştir. Bu yüzden parti Fransız ulusunun köklerini korumak ve köksüzleştirme sürecini tersine çevirmek için tasarlanmış bir kültürel politikaya öncelik verilmesi gerektiğini savunmuştur.

Front National'a göre Fransız ulusal kimliği iki bin yılı aşkın süredir, üç büyük Avrupa kültürü unsuru olan Kelt, Germen ve Greko-Latin (Roma Hıristiyanlı̆̆ı tarafından şekillendirilen) gelenekleriyle yoğrulmuştur. Geçmiş ylllarda gelen göçmenler de Avrupa ülkelerinden geldikleri 
için asilimilasyonları daha kolay olmuştur. Ne var ki en yeni göçmenler Mağrip bölgesinden, Türkiye'den, Güney Afrika'dan ve Sahra-altı Afrika’sından gelmişlerdir ve bu gelen nüfus "etnik gettolar ve bölgeler" oluşturma eğilimindedirler. Bu durum da entegrasyonda temel arıza belirtilerinin görülmesine ve yıkıı sonuçların ortaya çıkmasına sebebiyet vermektedir (Betz, 2003:196-97).

Hollanda'da Pim Fortuyn da benzer bir söylemin temsilciliğini üstlenmiştir. Fortuyn, Müslümanların kadınlara -ve eşcinsellere- ayrımcı davranan, gerici, Hollanda'nın eşitlikçi kültürüyle uzlaşamayacak, kısaca hoşgörüye yeteneksiz bir kültürden gelmeleri dolayısıyla dışlanmaları gerektiğini savunur. Göçmen meselesi husususunda taviz verilebilecek son noktanın, asla yeni göçmen kabul edilmemesi ve mevcut göçmenlerin Hollanda toplumuna entegrasyonunun sağlanması olacağını ifade etmiştir. Böylece Fortuyn Hollanda'nın liberal siyasi kültürünün övünç kaynağı olan hoşgörünün nasıl bir dışlama aracı haline getirebildiğinin örneğini vermiştir (Bora, 2005: 254).

Sadece ulusal kimliğin korunması değil aynı zamanda var olduğu savunulan Avrupa kimliğinin tehdit altına girdiği de aşırı sağ parti sözcüleri tarafından sıkça dile getirilmektedir. Tehdit yaratan yabancı istilası ve "Amerikan kültür emperyalizmi" karşısında Avrupa kültürünün nefs-i müdafaa haklarından bahsedilirken, ırkçı tanımlamalara da yer verilmiştir. Göç ve çokkültürlülük, Avrupa halklarının yıkıntıları üzerine "Anglofon ve totaliteryen bir Küresel Köy" inşa etmek için, Avrupa halklarını yok etmek için tasarlanmış daha geniş bir küreselleşme sürecinin unsurları olarak görülür. Onlara göre bu süreç anonim değildir. Küresel bir imparatorluk kurmak için Amerika ve Müslümanlar eliyle hayata geçirilmeye çalışılmaktadır. İtalya'da Lega Nord, Amerika’nın küreselleşme ideolojisiyle bağlantılı olarak, Avrupa'ya "çok-ırklı toplum" anlayışını empoze etmek istediğini ve bu sayede Eski Kıta’yı zayıflatmanın ve Amerikan süper gücünü hakim kılmanın hesaplarını yaptığını iddia etmiştir. Lega Nord, bu çabaları tersine çevirebilmek için, halkın kendi kültürel kimliklerini savundukları, kendi topraklarını yeniden ayırdıkları farklılıkçı bir dünya vizyonuna ihtiyaç olduğunu savunmuştur. Bu küreselleşmeye, Amerikan ve İslam emperyalizmine karşı kullanılabilecek en etkili silah olarak tarif edilmiştir (Betz, 2003:201).

$\mathrm{Bu}$ minvalde $\mathrm{AB}$ projesi ve bütünleşme süreçleri de aşırı sağ siyasi kanadın boy hedefi haline gelmekten kurtulamamıştır. Üye devletlerin yetkilerini topluluğa devretmesi ve birliğin faaliyet alanlarının artması, daha fazla ülkenin birliğe üye kabul edilmesi gibi durumlar aşırı sağın oylarının artmasına neden olmaktadır. Aşırı sağ, $A B$ bütünleşmesinin ulus-devlet yapısını zayıflattığı iddiası üzerinden siyasi rant elde etmeye çalışmakta ve $A B$ içindeki yabancıların varlığını, iddiasını güçlendirecek unsurlar olarak kullanmaktadır. Genişleme dalgalarının, göç ve benzeri faktörlerle özellikle ekonomik anlamda $\mathrm{AB}$ vatandaşlarının gelecekleri hakkında yarattığ 1 sanal korku, aşırı sağ siyasi partiler tarafından yaygın biçimde kullanılmaktadır. Genişleme dalgasının ortaya çıkaracağı yeni durumu, kitlelerdeki endişeyi artırmak için kullandıkları "Polonyalı muslukçu" örneği üzerinden sunan aşırı sağ, yeni katılan üyelerden gelecek göçmen nüfusun Batı Avrupa'da ikamet eden yurttaşların işlerini elllerinden alacağı korkusunu yaymaya çalışmıştır (Yılmaz, 2008:57-58). 


\section{I Eylül Sonrası Artan İslam Karşıtlığı}

11 Eylül olayları göçmen/yabancı karşıtı tutumların değişmesinde önemli bir dönüm noktası olmuştur. Herşeyden evvel aşırı-sağ partilerin önceden daha dar kitleye hitap eden İslam karşıtı söylemleri, daha önceleri bu söylemlere kulak kabartmayan anaakım parti seçmenleri nezdinde de etkili olmaya başlamıştır. Yani İslam karşıtllğı marjinal bir durum olmaktan çıkarak, daha sıradan bir hal almaya başlamıştır. Özellikle Madrid ve Londra'da gerçekleştirilen saldırılar Avrupa'da İslam karşıtı algının güçlenmesinde önemli bir rol oynamıştır. Aşırı sağ, 11 Eylül olaylarının Müslümanlar ve İslam hakkında yarattığı bu olumsuz havayı fırsata çevirmekte gecikmemiştir. Özellikle Samuel Huntington'ın ortaya attı̆̆ı Medeniyetler Çatışması (Huntington, 1993) tezine çokça atıfta bulunularak İslam'in, Avrupa ve Hiristiyan medeniyetine savaş açtığı iddia edilmiştir. Aşırı sağın dışlayıcı söyleminin merkezine bu saldırılardan sonra İslam ve Müslümanlar oturmuştur.

"Farklılıkçı ırkçılık" yaklaşmının, bu dışlama tarzında da kullanıldığını belirtmek gerekir. $\mathrm{Bu}$ yaklaşım doğrultusunda İslam, belli kalıplar içerisinde anlamlandırılmaya çalışılır. Buna göre İslam; yekpare ve statik, diğer kültürlerin değerlerini paylaşmayan ayrıksı ve "öteki", irrasyonel, ilkel ve Batı'dan aşağı, saldırgan, şiddet yanlısı, siyasi ve askeri çıarları artırmak için kullanılan bir ideoloji, Batı eleştirilerine karşı hoşgörüsüz, Müslümanlara karşı dışlamacı ve ayrımcı pratikleri haklılaştıran, Müslüman karşıtı düşmanlığı normal ve doğal hale getiren bir din olarak damgalanabilmektedir (Taras, 2013:418). İslam'ın sadece bir din değil, totaliteryen bir ideoloji olduğu Avrupa'daki Müslüman topluluğa karşı sağın temel argümanlarından birisi olmuştur. Hatta işi İslam'ı Nazizm'le karşılaştırmaya kadar götürenler de olmuştur. Hollandalı Partij voor de Vrijheid lideri Geert Wilders 2007 yılında Kur’an'ın yasaklanması çağrısında bulunduğunda, Kur'an'1 Hitler' in Kavgam kitabı gibi modern Batı demokrasisinin simgesi her şeyi yıkmak isteyen, ölüm ve yıkıma teşvik eden hasta ve faşist bir ideolojinin kaynağı olarak göstermiştir (Betz-Meret, 2009:320). Yine Avusturya FPÖ lideri Heinz Christian Strache İslam'ı totaliteryen bir yasal ve sosyal sistemi öngören, yirmibirinci yüzyll faşizmi olarak nitelendirmekten geri durmamıştır. Yine Strache, Müslüman ülkelerden gelen göçü "üçüncü Türk kuşatması" olarak adlandırmış ve buna her anlamda direnilmesi gerektiğini vurgulamıştır (Betz-Meret, 2009:320).

Böylesine önyargılar üzerinden yeniden üretilen İslam karşıtlğ̆ı, Avrupa'da yaşayan Müslümanların hedef haline gelmesine ve onların giderek bir "iç düşman" kategorisinde değerlendirilmesine neden olmaktadır. Aşırı sağ partiler bu Müslüman karşıtı söylemi, yabancı düşmanlığını ve İslamofobi'yi; göç, ulusal güvenlik meseleleri ve işsizlik, göçmenler ve "refah şovenizmi” gibi konularla bağlantılı biçimde işlemektedirler (Yeşilyurt-Gündüz, 2010: 41). Esasında İslam karşıtlığı 11 Eylül öncesinde ekonomik kaygılarla öne çıkan bir durumken, bu saldırılardan sonra Müslümanların kültürel özellikleri de dikkat çekmeye ve tepki toplamaya başlamıştır. Bunun sonucunda ekonomik dışlamayla kültürel dışlama örtüşür hale gelmiştir (Akdemir, 2009: 16) 
Tablo-2: 2010 Tarihi İtibariyle Bazı Avrupa Ülkelerindeki Müslüman Nüfus

\begin{tabular}{|l|c|c|}
\hline ÜLKELER & 2010'daki Yaklaşık Müslüman Nüfus & Müslümanların Nüfus Yüzdesi \\
\hline Avusturya & 474.000 & 5.7 \\
\hline Belçika & 638.000 & 6.0 \\
\hline Danimarka & 226.000 & 4.1 \\
\hline Finlandiya & 42.000 & 0.8 \\
\hline Fransa & 3.574 .000 & 5.7 \\
\hline Almanya & 4.119 .000 & 5.0 \\
\hline Yunanistan & 527.000 & 4.7 \\
\hline İrlanda & 43.000 & 0.9 \\
\hline İtalya & 1.583 .000 & 2.6 \\
\hline Lüksemburg & 13.000 & 2.7 \\
\hline Hollanda & 914.000 & 5.5 \\
\hline Norveç & 144.000 & 3.0 \\
\hline Portekiz & 22.000 & 0.2 \\
\hline İspanya & 1.021 .000 & 2.3 \\
\hline İsveç & 451.000 & 4.9 \\
\hline İsviçre & 433.000 & 5.7 \\
\hline Birleşik Krallık & 2.869 .000 & 4.6 \\
\hline Toplam & 17.094 .000 & \\
\hline
\end{tabular}

Kaynak: http://www.pewforum.org/2010/09/15/number-of-muslims-in-western-europe-html/

İran Devrimi, Körfez Savaşı, 11 Eylül olayları, Amsterdam'da ressam Theo van Gogh'un öldürülmesi, Madrid ve Londra tren bombalamaları, Danimarka'da yayınlanan karikatür olayı sonrası yaşananlar, kamusal tartışmanın sürekli olarak İslam’da şiddet meselesi etrafında dönmesine neden olmuştur. Bunun sonucu olarak aşırı sağ partiler de çeşitli açıklamalarla ve önerilerle ortaya çıkmışlardır. Örneğin İsviçre Halk Partisi'nin iki lideri Ulrich Schlüer and Oscar Freysinger camilere minare yasağı getirilmesini önermiştir. Minarelerin masum dini yapılar olarak görülemeyeceğini savunan bu iki lider, minarelerin generallerin stratejik askeri haritalarda fethettikleri bölgeyi işaretlemek için kullandıkları bayrakla aynı işleve sahip olduğunu öne sürmüştür. Minare olan bölgeler, Müslümanların işgal ettikleri yerleri simgelediğini iddia ederek camilere minare yapımına yasaklama getirilmesi gerektiğini savunmuşlardır (Green, 2012:342-43). Yine Belçika Flaman bölgesinden Entegrasyon Bakanı camilerin kamu fonundan yararlanabilmesi için, Arapça yapılan ritüellerin dışında Hollanda dilinin kullanılması gibi bazı kriterleri yerine getirmek zorunda olduğunu belirtmiştir (Yeşilyurt-Gündüz, 2010: 41). Söz konusu İslam karşıtı anlatıyı yalnızca aşırı-sağ partilerin sahiplendiklerini ileri sürmek yanlış 
olur. İslam karşıtı söylemin daha kabul edilebilir biçimdeki hallerine, Fransa Cumhurbaşkanı Sarkozy'nin, Almanya Başbakanı Merkel'in, İngiltere Başbakanı Cameron'ın ve eski İtalya Başbakanı Berlusconi’nin ve hatta Papa XVI. Benedictus'un sözlerinde de rastlamak mümkündür. İslam karşıtı anlatı sadece aşırı sağın tekelinde olan bir husus değildir, onlar bunun sürmesinde ve olumsuz etkilerinin yayılmasında tek sorumlu da değildirler (Green, 2012:342-43).

Avrupa aşırı sağında Müslümanlara ve İslam’a karşı önyargılar, hoşgörüsüzlük ve tepki gittikçe artarken, Hıristiyan motiflere ve temalara daha fazla ilgi duyulmaya başlandığını görüyoruz. Hatta "Hıristiyanlığa dönüş" olarak ifade edilebilecek bu durum kimi zaman bu partiler için kendisinin daha önceki pozisyonunu red manası da taşımıştır. Örneğin İtalya'daki Lega Nord Katolik Kilisesini, İtalyan birliğinin sağlanmasından bu yana baskıcı merkeziyetçi güçlerle danışıklı dövüş içerisinde olduğu ithamıyla, 1990'ların sonlarına kadar, Kuzey'in özgürlüğünün doğal düşmanı olarak tanımlamıştır. Ancak 11 Eylül saldırılarından sonra partinin Kilise'ye bakışı büyük bir değişim göstermiştir. Bu saldırılar sonrası İslam parti için başlıca tehdit halini almış ve mücadele edilmesi gereken bir düşman olarak görülmeye başlanmıştır. Papa Ratzinger'in İslam ve şiddeti eşleştiren yorumlarıyla birlikte Lega Nord Kilise'yle aynı pozisyonda yer aldığını fark etmiştir. Ratzinger'in açıklamasından sonra parti üyesi bir yetkili Hıristiyanlığa ait derin anlam ve köklerin neler olduğunu yeniden hatırlattığ 1 için Kilise’ye teşekkür etmiştir (Zuquete, 2008: 325).

Aşırı sağ parti repertuarının eksilmez parçalarından biri olarak görülen anti-semitizm için de 11 Eylül sonrasında benzer bir değişimin varlığını gözlemlemek mümkündür. Gerçekten de anti-semitizm güvensiz, yabanc1, köksüz ve ulusun birliğine karşı uluslararası komplolarla meşgul Yahudi imgesinden hareketle Avrupa aşırı sağının temel özelliklerinden birisi olmuştır. Ancak yakın zamanlarda bu partilerde Yahudi yanlısı (pro-Jewish) bir söylemsel değişim meydana gelmiştir. Bu eğilim yine de düzensiz olmuştur ve Almanya'nın Nationaldemokratische Partei Deutschlands (NPD) örneğinde olduğu gibi kimi aşırı sağ partiler anti-semitik kökenlerine sadık kalmışlardır. Flaman Vlaams Blok ise bu noktada, artan İslam karşıtllğının da etkisiyle, Yahudiliğin ve Siyonizmin sadık destekçisi söylemiyle dikkati çeker. Partinin önemli isimlerinden Filip Dewinter Ortadoğu'da ifade özgürlüğü, din özgürlüğü ve hukukun üstünlüğüne sahip tek millet olarak nitelediği İsrail’i Avrupa'nın doğal müteffiki sıfatıyla övmüştür (Zuquete, 2008: 327-28). Fransa aşırı sağının ana kuramcılarından birisi olan Guillaume Faye ise Avrupa kimliğini savunanların obsesif ve kronik anti-Yahudiliği bırakması gerektiğini belirtmiş, gerçek tehlikeyi üçüncü dünya ve İslam'dan gelen kolonizasyon olarak işaret etmiştir (Zuquete, 2008: 328-29).

Özetle 11 Eylül sonrasında anti-semitist söylemin yerini büyük ölçüde İslamofobi almıştır. Hıristiyanlığın yeniden hatırlanmasına benzer biçimde Avrupa kültürünün oluşumundaki Yahudiliğin etkisi daha fazla dile getirilmeye başlanmıştır. Aşırı sağın arasının çok da iyi olmadığ Hıristiyanlık ve Yahudilik, İslami tehdit algılaması karşısında yerli oluşları nedeniyle daha tercih edilir sayılmıştır. Zihinlerde inşa edilen Judeo-Hıristiyan Avrupa kültürü Müslümanlara ve İslam’a karşı savunulması gereken bir değer olarak öne çıkarılmıştır. 


\section{Sonuç}

Avrupa'da aşırı sağ partiler özellikle son yirmi yılı kapsayan süreçte önemli bir yükseliş göstermiş ve hatırı sayılır seçim başarıları elde etmişlerdir. Bu durum karşısında sözkonusu aşırı sağ partilerin neden seçmenlerin tercihlerinde öne çıktığı sorusuna yanıt aranmaya başlanmıştır. Bu izah denemelerinde bir grup araştırmacı, modernleşmenin sonuçlarından hoşnutsuz kitlelerin aşırı-sağ partilere kaydığını tespit ederken, bir diğer grup araştırmacı da siyasal yabancılaşmanın ve hoşnutsuzluğun insanları aşırı sağ partilere ittiğini bulgulamıştır. Başkaca araştırma yapanlar ise bu partilerin seçmenlere sunduğu önerilerin cazibesine dikkati çekerken, medyanın artan etkisine ve liderlerin bu medya ağını etkin kullabilme becerisine de atıfta bulunmuşlardır.

Bunun dışında çağdaş aşırı sağ partiler, klasik faşist oluşumlardan farklılaşan özelliklere sahip yapılarıyla dikkati çekmektedirler. Demokrasiye formel olarak karşı olmama ancak onun liberal vasıflarla donatılmasından rahatsız olma ilk dikkati çeken özellikleridir. Bunun yanında, partilerin serbest piyasa ekonomisine karşı olmayışları da ayrıca not edilmesi gereken bir durumdur. Konumuz açısından ise en önemli farklılık, ırkçılık konusunda ortaya çıkmaktadır. Klasik faşizmin mütemmim cüzü sayılabilecek olan ırkçı anlayış, biyolojik farklılıklar üzerinden inşa edilirken, ırklar arasında bir hiyerarşi kurma çabası kendini gösterir. Aşırı sağın ırkçılık anlayışı ise kültürel farklılıklara dikkat çeken, kültürlerin birbirinden farklı yapılarının olduğunu öne süren bir vasatı temsil eder. Bu anlayış uyarınca kültürlerin birbirine karışmaması gerektiği sürekli tekrarlanır. Dışlama pratikleri ise kültürel açıdan uyumsuz olan etnik grupların ayrı tutulması üzerinden gerçekleşir. Buna göre bazı kültürlerin hoşgörüsüz, demokratik değerlerden yoksun olması gibi iddialar onların dışlanmasına hizmet eder. Avrupa'da aşırı sağ işte bu farklılıkçı ırkçı yaklaşımı kullanarak göçmen karşıtı tutumunu meşrulaştırmaya çalışır. Kendi kültürel kimliğinin bütün pozitif değerleri kapsadığını öne sürerek, bu değerlerden yoksun kimliklerin dışarıda tutulmasını ister. 11 Eylül sonrası dönemde giderek artan biçimde bu dışlama mekanizmasının İslam'ı ve Müslümanları hedef tahtasına koyduğunu görüyoruz. Hoşgörüsüzlük, şiddet yanlısı olma, suç oranlarını artırma, kadınları aşağılama gibi olgular İslam’la ilişkilendirilmiş, bu vasıflara sahip olmaları onların dışlanmaları için yeter sebep kabul edilmiştir. Aşırı sağ partiler, Müslümanların bu vasıflarını Avrupa'ya taşıyacakları ve Avrupa'nın demokratik, hoşgörülü siyasi kültürünü bozacakları korkusunu tüm kıtaya yaymaya çalışmışlardır. İslam ve Müslümanlar aşırı sağ tarafından Avrupa için esas tehdit odağı olarak sunulurken, anti-semitist söylemin yeni dönemde en hafif tabirle zayıfladığını görüyoruz. Güncel İslami tehdidin daha ciddi olduğundan hareketle aşırı sağ gündeminden -belki de şimdilik- anti-semitizmi çıkarmış görünmektedir. 


\section{Kaynakça}

Akçapar Köşer, Şebnem (2012) "Uluslararası Göç Alanında Güvenlik Algılamaları ve Göçün İnsani Boyutu”, Ihlamur S.G.ve Öner N.A.Ş. (der) Küreselleşme Çağında Göç içinde, İstanbul: İletişim Yayınlar1: 563-577.

Akdemir, Erhan (2009) “11 Eylül 2001, 11 Mart 2004 ve 7 Temmuz 2005 Saldırılarının Ardından İslam’ın Avrupa'da Algılanışı”, Ankara Avrupa Çalışmaları Dergisi, 8 (1): 1-27.

Betz, Hans-Georg (2003) "Xenophobia, Identity Politics and Exclusionary Populism in Western Europe", Socialist Register, 39:193-209.

Betz, Hans-George-Meret, Susi (2009) "Revisiting Lepanto: The Political Mobilization Against Islam in Contemporary Western Europe”, Patters and Prejudice, 43 (3-4): 313-334.

Bora, Tanıl (2005) “Avrupa'da Radikal Sağ ve Post-Faşizmin Zihniyet Dünyası”, (ek-söz), Vural H.S. (yaz.) Avrupa'da Radikal Sağın Yükselişi içinde, İstanbul: İletişim Yayınları.

Bora, Tanıl (2006) Medeniyet Kaybı: Milliyetçilik ve Faşizm Üzerine Yazılar, İstanbul: Birikim Yayınları.

Boztepe, Kemal (1997) Avusturya'da “Aşırı Sağ”ın Önlenemeyen Yükselişi”, Toplumbilim, 7: 95-102.

Green, H. Todd (2012) “Who Speaks for European's Muslim?”, Cross Currents, 62 (3): 337-349.

Griffin, Roger (2014) Faşizmin Doğası, çev: Ali Selman, İstanbul: İletişim Yayınları.

Gündüz-Yeşilyurt, Zuhal (2010) “The European Union at 50-Xenophobia, Islamophobia and the Rise of the Radical Right", Journal of Muslim Minority Affairs, 30 (1): 35-47.

Hainsworth, Paul (2008) The Extreme Right in Western Europe, Oxford: Routledge.

Huntington, Samuel P. (1993) “The Clash of Civilizations?”, Foreign Affairs, 72 (3): 22-49.

Ignazi, Piero (2003) Extreme Right Parties in Western Europe, Oxford: Oxford University Press.

Karapin, Roger (1998) "Radical Right and Neo-Fascist Political Parties in Western Europe", Comparative Politics, 30 (2): 213-234.

Lifland, Amy (2012) "Right Wing Rising", Harward International Review, Winter: 9-10.

Mann, Michael (2004) Fascist, Cambridge: Cambridge University Press.

Minkenberg, Michael (2011) The Radical Right in Europe an Overview, Verlag Bertelsmann Stiftung, E-Book.

Minkenberg, Michael (2013) "The European Radical Right and Xenophobia in West and East: Trends, Patterns and Challenges", Ralf Melzer-Sebastian Serafin (ed), Right-Wing Extremism in Europe içinde, Berlin: Friedrich-Ebert Foundation: 9-35.

Mudde, Cas (1996) “The War of Words Defining the Extreme Right Party Family”, West European Politics, 19 (2): 225-248.

Mudde, Cas (2011) “Who's Afraid of the European Radical Right”, Dissent, 58 (4): 7-11.

Passmore, Kevin (2014) Faşizm, çev: Sinem Gül, İstanbul: Dost Yayınları.

Paxton, Robert (2014) Faşizmin Anatomisi, çev: Hakan Atay-Hivren Demir Atay, İstanbul: İletişim Yayınları.

Report of the Group of Eminent Persons of the Council of Europe (2011), Living Together: Combining Diversity and Freedon in 21st-Century Europe, https://cps.ceu.hu/sites/default/files/field_ attachment/news/node-22221/GEP-living-together-2010.pdf

Rydgren, Jens (2007) "Immigration Sceptics, Xenophobes or Racist? Radical Right-Wing Voting in Six West European Countries”, European Journal of Political Research, 47 (6) : 737-765.

Rydgren, Jens (2007) “The Sociology of Radical Right”, The Annual Review of Sociology, 33: 241-62 
Taguieff, Pierre Andre (2001) The Force of Prejudice: On Racism and its Doubles, Minnesota: The University of Minnesota Press.

Taras, Raymond (2013) “Islamophobia Never Stands Still: Race, Religion and Culture”, Ethnic and Racial Studies, 36 (3).

Van der Brug, Wouter; Fennema, Meindert; Tillie, Jean (2000), “Anti-Immigrant Parties in Europe: Ideological or Protest Vote”, European Journal of Political Research, 37 (1), 77-102.

Vardar, Deniz (1997) “Fransa'da UC (Ulusal Cephe, Front National) Aşırı Sağ’dan Yeni Sağ’a”, Toplumbilim, 7:27-34.

Vural, Hasan Saim (2005) Avrupa'da Radikal Să̆’n Yükselişi, İstanbul: İletişim Yayınları.

Waal, van der Jeroen-Achterberg, Peter-Oorschot, van Wim (2011) "Why Are in Some European Countries Immigrants Considered Less Entitled to Welfare", Norface 2011 Conference, http:// cream.conference-services.net/resources/952/2371/pdf/MECSC2011_0161_paper.pdf

Wiggen, Mette (2012) "Rethinking Anti-Immigration Rhetoric After the Oslo and Utoya Terror Attacks", New Political Science, 34 (4): 585-604.

Yılmaz, Fatma (2008) Avrupa'da Irkçılık ve Yabancı Düşmanlığı, Ankara: USAK Yayınları.

Yumul, Arus (1998) “Evrenselcilik ve Yerelcilik Arasında Irkçılığın Dili”, Foreign Policy (Türkiye Baskısı), Bahar, 1 (1): 139-147.

Zaslowe, Andrej (2007) "The Dark Side of European Politics: Unmasking the Radical Right, Journal of European Integration, 26 (1): 61-81.

Zuquete, Jose Pedro (2008) “The European Extreme Right and Islam: New Directions”, Journal of Political Ideologies, 13 (3): 321-344. 
